The Comanche Empire 
THE LAMAR SERIES IN WESTERN HISTORY

The Lamar Series in Western History includes scholarly books of general public interest that enhance the understanding of human affairs in the American West and contribute to a wider understanding of the West's significance in the political, social, and cultural life of America. Comprising works of the highest quality, the series aims to increase the range and vitality of Western American history, focusing on frontier places and people, Indian and ethnic communities, the urban West and the environment, and the art and illustrated history of the American West.

E D I T O R I A L B OAR D

Howard R. Lamar, Sterling Professor of History Emeritus, Past President of Yale University

William J. Cronon, University of Wisconsin-Madison

Philip J. Deloria, University of Michigan

John Mack Faragher, Yale University

Jay Gitlin, Yale University

George A. Miles, Beinecke Library, Yale University

Martha A. Sandweiss, Amherst College

Virginia J. Scharff, University of New Mexico

David J. Weber, Southern Methodist University

Robert M. Utley, Former Chief Historian National Park Service

R E C E N T T I T L E S

Vicious, by Jon T. Coleman

The Comanche Empire, by Pekka Hämäläinen

Frontiers, by Robert V. Hine and John Mack Faragher

Revolution in Texas, by Benjamin Heber Johnson

Emerald City, by Matthew Klingle

Murder in Tombstone, by Steven Lubet

Making Indian Law, by Christian W. McMillen

Fugitive Landscapes, by Samuel Truett

Bárbaros, by David J. Weber

F O R T H C O M IN G T I T L E S

The War of a Thousand Deserts, by Brian Delay

The Bourgeois Frontier, by Jay Gitlin

Defying the Odds, by Carole Goldberg and Gelya Frank

The Far West in the Twentieth Century, by Earl Pomeroy

César Chávez, by Stephen J. Pitti

Geronimo, by Robert Utley 


\section{THE COMANCHE}

\section{EMPIRE}

Pekka Hämäläinen

Published in Association with The William P. Clements Center for Southwest Studies, Southern Methodist University

Yale University Press

New Haven \& London 
Published with assistance from the Louis Stern Memorial Fund.

Copyright ( 2008 by Yale University. All rights reserved.

This book may not be reproduced, in whole or in part, including

illustrations, in any form (beyond that copying permitted by

Sections 107 and 108 of the U.S. Copyright Law and except by reviewers for the public press), without written permission from the publishers.

Set in Electra type by Tseng Information Systems, Inc.

Printed in the United States of America.

The Library of Congress has cataloged the hardcover edition as follows:

Hämäläinen, Pekka, 1967-

The Comanche empire / Pekka Hämäläinen.

p. cm. - (The Lamar series in western history)

Includes bibliographical references and index.

"Published in association with the William P. Clements Center

for Southwest Studies, Southern Methodist University."

ISBN 978-0-300-12654-9 (cloth : alk. paper)

1. Comanche Indians-History. 2. Comanche Indians-Government relations.

3. United States-History-19th century. 4. Mexico-History-To 1810.

I. William P. Clements Center for Southwest Studies. II. Title.

$$
\begin{gathered}
\text { E99.C } 85 . \mathrm{H} 272008 \\
978.004^{\prime} 974572-\mathrm{dc22} \\
2007041809 \\
\text { ISBN } 978-0-300-15117-6 \text { (pbk. : alk. paper) }
\end{gathered}
$$

A catalogue record for this book is available from the British Library.

This paper meets the requirements of ANSI/NISO Z39.48-1992 (Permanence of Paper).

It contains 30 percent postconsumer waste $(\mathrm{PCW})$ and is certified by the Forest Stewardship Council (FSC).

$\begin{array}{llllllllll}10 & 9 & 8 & 7 & 6 & 5 & 4 & 3 & 2 & 1\end{array}$ 